\title{
The Use of Edmodo Apps in Flipped Classroom Learning. How is the Students' Creative Thinking Ability?
}

\author{
Heny Kusuma Widyaningrum ${ }^{1}$, Cahyo Hasanudin ${ }^{2 *}$, Ayu Fitrianingsih ${ }^{3}$, Dwi Erna Novianti ${ }^{4}$, Kundharu Saddhono ${ }^{5}$, \\ Nunung Supratmi ${ }^{6}$ \\ ${ }^{1}$ Primary Teacher Education, Universitas PGRI Madiun, Madiun 63118, Indonesia \\ ${ }^{2}$ Indonesian Language and Literature Education Department, IKIP PGRI Bojonegoro, Bojonegoro 62114, Indonesia \\ ${ }^{3}$ English Education Department, IKIP PGRI Bojonegoro, Bojonegoro 62114, Indonesia \\ ${ }^{4}$ Mathematics Education Department, IKIP PGRI Bojonegoro, Bojonegoro 62114, Indonesia \\ ${ }^{5}$ Graduate School of Universitas Sebelas Maret Surakarta, Surakarta 57126, Indonesia \\ ${ }^{6}$ Faculty of Teacher Training Education, Universitas Terbuka Jakarta, Jakarta 15418, Indonesia
}

Corresponding Author Email: cahyo.hasanudin@ikippgribojonegoro.ac.id

https://doi.org/10.18280/isi.250109

Received: 1 November 2019

Accepted: 27 January 2020

\section{Keywords:}

flipped classroom, Edmodo apps, creative thinking ability, a course of Indonesian language and literature study

\begin{abstract}
The study aims to investigate whether there is an influence of Edmodo apps in flipped classroom learning on the students' creative thinking ability in the course of Indonesian Language and Literature Study. This study is quasy experimental research that was held at the fourth semester students in Class A and Class B of primary teacher education in Universitas PGRI Madiun, Indonesia. Class A is as the experimental class and class B is as the control class. The population is chosen using cluster random sampling technique. This study uses instruments of creative thinking ability test. Techniques in collecting data are observations, documentations, and tests. The instrument is validated using content validation. The normality test uses Lilliefors model because the data is single data. The homogeneity test uses Chi Square formula. Hypothesis is tested using t-test. Based on the result of test decision and observations, it can be concluded that the use of Edmodo apps in flipped classroom learning gives better influence to the students' creative thinking ability in the course of Indonesian Language and Literature Study.
\end{abstract}

\section{INTRODUCTION}

The course of Indonesian Language and Literature Study has been taught in primary teacher education. It includes morphological, semantic, phonological, and syntax studies. The core study is inseparable about grammar. It learns about the basics and processes of forming sentences in a language [1, 2]. Grammar does not only discuss about the formation of a sentence [3-5]. However, it also discusses about discourses, sentences, clauses, and phrases [6]. The result of Hasanudin's research shows that the novel entitled "Sang Pencuri Warna [The Colours Thief]" by Yersita contains syntactic elements such as phrases, clauses, and sentences [7]. It can be said that syntax competence includes the aspects of knowledge, skill, and mastery about language units (sentences, clauses, and phrases). These units have to be well-mastered by students. Therefore, they need to have creative thinking ability.

The creative thinking ability is the ability to find many possible answers to a problem [8]. The results of logical and divergent thinking are not only related to a good and interesting finding, but also the implementation of it [9]. A study by Hasanudin and Fitrianingsih shows that students are able to think creatively in creating poems inspired by their personal experiences. They have a large vocabulary and are able to use correct diction. The use of it in accordance with personal experience make them think creatively in creating their own poems [10].

The indicators of creative thinking are fluency, authenticity, and elaboration [11]. In line with syntactic learning, the students who have good creative thinking are able to find the appropriate formation of grammar in a text based on their logical and divergent thinking. The research by Saddhono, Hasanudin, and Fitrianingsih shows that at the level 4 of creative thinking ability, students are very creative in finding phrases and arrange it into compound sentences. By using their creativity, the students are able to give the correct answers about phrases of pictures in the application [12].

Learning is an effort to develop thinking creativity so that students can improve their knowledge and thinking ability [13] Simon says that knowledge has a role in the formation of behavior [14]. In fact, the lack of students' abilities and the learning process that does not run well cause the students' learning outcomes are being low. The data found that $70 \%$ is determined by internal factor and $30 \%$ is determined by external factor (learning environment) [13]. The learning process that is not well managed, is strongly said as a cause of low learning outcomes, one of which is the learning method is less fun.

Flipped Classroom is the right solution for students in creating fun and effective learning method. It is a reversal of the traditional method. The traditional method is a condition in which the teacher explains the material in class and the students complete the assignment at home $[15,16]$. In learning at the classroom, the students only carry out discussion and complete the assignments from the lecturer [17-19].

The flipped classroom strategy has several advantages, such 
as more effective discussion activities and easier completion of students' assignments because more time is given and more flexibility in doing it [20]. Hasanudin, Fitrianingsih, and Saddhono explain that flipped classroom learning with CyberLink Power Director media apps has already well referred to the negotiation text structure according to the Ministry of Education and Culture [21]. It also can be integrated with the Wondershare Filmora Version 7.8.9 media apps in learning 2013 curriculum in Indonesia by using a scientific approach [22].

Flipped classroom is very suitable to be implemented by using Edmodo web media because it is a fun online web that provides new experiences in learning [23]. Moreover, it can be quickly and easily accessed by students wherever and whenever they are [24]. In other word, the students can learn without being limited by space, time, and distance.

A study by Tania, Jumadi and Astuti reveals that the application of e-handout assisted by problem based learning model using Edmodo can improve the students' creative thinking ability [25]. Pertiwi, et.al. explains that Edmodo media can enhance students' mathematical proving ability as well as its achievement [26]. Furthermore, Çankaya, Durak, and Yünkül argue that Edmodo's contribution to learning as making learning fun appeared to be as attracting students' attention, appropriate for future students, making teachers work easier, making the lesson effective and organized [27]. Based on these studies, the researchers are eager to implement Edmodo apps to flipped classroom learning in the course of Language and Literature Study so they know how student's creative thinking ability is.

\section{RESEARCH METHODOLOGY}

This study is a quasi-experimental research. According to Sugiyono, quasi experimental design is a development of true experimental design, which is difficult to be carried out. It has a control group, but it cannot be totally used to control the external variables that influence the implementation of the experiment [28]. This research does not control or manipulate all relevant variables except for a few of the variables studied.

The study was designed by giving creative thinking test. It involved two groups of samples that were treated in different ways. The first group as the experimental class was taught in flipped classroom learning by using Edmodo apps. On the other hand, the second group as the control class was taught by using direct instruction. The design could be seen clearly in Table 1.

Table 1. The research design

\begin{tabular}{ccc}
\hline Group & Treatment & $\begin{array}{c}\text { The results of } \\
\text { creative thinking test }\end{array}$ \\
\hline Experimental class & $X$ & $T_{l}$ \\
Control class & $Y$ & $T_{1}$ \\
\hline
\end{tabular}

$X=$ Flipped Classroom Learning by using Edmodo apps

$Y=$ Direct Instruction Learning

$T_{l}=$ Creative thinking test

\subsection{Time and place of research}

This research was conducted in the fourth semester students of Primary School Teacher Department, Faculty of Teacher Training and Education, Universitas PGRI Madiun, Indonesia
It was conducted in course of Indonesian Language and Literature Study.

\subsection{Research subjects}

The research subjects were all fourth semester students of Primary School Teacher Department in A and B classes. The class A was used as an experimental class, and the class B is used as a control class. The researchers used cluster random sampling technique to determine the research sample. According to Sugiyono, it was a technique in which members of the population were taken randomly [29].

\subsection{Research instruments}

The instruments of this research were a test of creative thinking ability on the course of Indonesian Language and Literature Study and the observation sheets. The creative thinking test was used to determine the students' ability to think creatively on the materials of Indonesian Language and Literature study. It was delivered after the students attained the materials in flipped classroom learning by using Edmodo apps. It was essay test that was consisted of 5questions. The essay was used to determine the students' ability in thinking creatively viewed from the multiple answers given based on the indicators of creative thinking, i.e fluency, authenticity, and elaboration.

Another instrument was observation sheets that contained the assessment of students' activities in the learning process. The students' activities contained of the stages of flipped classroom learning by using Edmodo apps. It was check list form of the students' activities. The observation process was done by the observers, they were collaborators.

\subsection{Data collection techniques}

Techniques in collecting data used in this research were observation, documentation, and test techniques.

\subsubsection{Observation}

Observation is a technique that was done by deep monitoring and record-keeping systematically [30]. This technique was carried out to maintain the learning process such as in the discussion and students' participations in it. The observation technique aimed to investigate the students' learning activities in flipped classroom learning using Edmodo apps. This observation was carried out using observation sheets and the observers.

\subsubsection{Documentation}

Documents were records of past events. It was in forms of writings, drawings, or monumental works of someone [28]. In this research, documentation technique was needed to find out the data of students' final scores in the third semester. It was used as a calculation of the empirical validity test.

\subsubsection{Test}

Test method was as a basis for knowing the students' ability in understanding the materials that had been given. According to Sugiyono, to facilitate the arrangement of instruments, the matrix of instrument development or blueprint was needed [28]. It meant that blueprint was a form of matrix that was developed to arrange questions into tests in accordance with the guidelines, clear, and detailed. The arrangement of test 
items was composed based on the blueprint that had been made. The test method used in this research was a test of creative thinking ability. It consisted of essays arranged by referring to the materials given.

\subsection{Instrument validity techniques}

Validity is a dimension to show that an instrument is acceptable. A valid instrument has a high validity. On the other hand, an invalid instrument has a low validity [31].

The technique of validating instrument in this research was content validity. It would like to examine the extent to which the items of instrument covered the entire content of the objects to be measured. In this case, the objects were indicators that were already listed in the blueprint [32]. This content validation was used to measure the validity of the creative thinking ability test. A question was valid when it had high validity. The validity test had to correlate the score of an item from the total score. To know the coefficient correlation of a question, the formula of Product Moment Pearson could be used [30].

$$
r_{x y}=\frac{n \Sigma X Y-(X)(Y)}{\sqrt{\left\{n \Sigma X^{2}-(\Sigma X)^{2}\right\}\left\{n \Sigma Y^{2}-(\Sigma Y)^{2}\right\}}}
$$

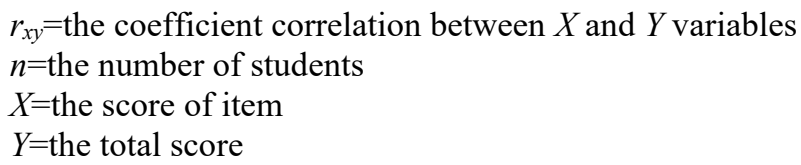

To know whether the item of question was valid or not, it had to compared the results of $r_{h i t}$ and $r_{\text {tabel }}$ Product Moment in $\alpha=0,05$. If the result showed that $r_{h i t}>r_{\text {tabel }}$, the item was valid. But, if the result showed that $r_{h i t}<r_{\text {tabel }}$, the item was invalid.

Besides, another thing used to test the instruments was reliability. The reliability test used for the instruments of creative thinking ability test was the formula of Alpha Cronbach for the questions in form of essays. The reliability of an instrument was the accuracy of evaluation tool. A test could be said as reliable when it gave a constant result. To know the reliability test, the formula of Alpha Cronbach could be used [30].

$$
r_{11}=\left[\frac{n}{(n-1)}\right]\left[1-\frac{\Sigma \sigma_{i}^{2}}{\sigma_{t}^{2}}\right]
$$

$r_{11}=$ the reliability

$n=$ the number of items

$\sigma_{i}^{2}=$ the number of varians scores in each item

$\sigma_{t}^{2}=$ the total varians

An instrument of research could be said reliable by using this technique when the coefficient reliability $r_{11}>0,6$.

\subsection{Data analysis technique}

The techniques of analysing data were:

\subsubsection{Prerequisite analysis test}

The prerequisite analysis test in this research were normality and homogeneity tests. Tests for normality with Lilliefors model because the data was in form of single data. The homogeneity test used the formula of Chi Square.

\subsubsection{Hypothesis testing}

After determining the values of normality and homogeneity, the normal and homogeneous data was used as a basis for testing the research hypothesis. T-test was used in this study. The hypothesis in this study was there is an influence of Edmodo apps in flipped classroom learning toward the students' creative thinking ability in the course of Indonesian Language and Literature study.

\section{FINDINGS AND DISCUSSION}

The aim of this research is to find out whether there is an influence of Edmodo apps in flipped classroom learning on the students' creative thinking ability in the course of Indonesian Language and Literature Study. In this study, the data were collected using two methods namely test and documentation methods. Test was used to investigate the students' creative thinking ability. Documentation was used to get additional data needed such as the students' attendance lists and results of final examination.

Furthermore, the researchers did the data analysis. The initial data analysis is prerequisite test which includes tests of normality and homogeneity. To find out whether the two classes are normally distributed or not, as well as homogeneous or not. After that, hypothesis testing is done by using t-test.

\subsection{Prerequisite test of students' scores}

Prerequisite test includes normality and homogeneity tests on samples. The data comes from the test scores of students' creative thinking ability in the control class and the experimental class.

\subsubsection{Normality test}

Normality test of final examination. This test is to find out whether the sample is normally distributed or not in both classes of samples (control class and experimental class). This test is by using the Liliefors method with a significance level of 0,05 , the test results can be seen in Table 2 .

Table 2. The analysis results of data normality test in final examination

\begin{tabular}{ccccc}
\hline Classes & $\begin{array}{c}\boldsymbol{L}_{\text {obser }} \\
\text { vation }\end{array}$ & $\boldsymbol{L}_{\text {table }}$ & $\begin{array}{c}\text { Test } \\
\text { Decisions }\end{array}$ & $\begin{array}{c}\text { Data } \\
\text { Distributions }\end{array}$ \\
\hline Control & 0,1082 & 0,148 & $\begin{array}{c}\mathrm{H}_{0} \text { is } \\
\text { accepted } \\
\mathrm{H}_{0} \text { is } \\
\text { accepted }\end{array}$ & $\begin{array}{c}\text { Normal } \\
\text { Distribution } \\
\text { Normal } \\
\text { Distribution }\end{array}$ \\
\hline
\end{tabular}

The amount of samples in both classes are $n_{l}=36$ with a significance level of $\alpha=5 \%$. The value of $L_{\text {hitung }}$ is obtained from the formula $L=\operatorname{Maks}\left|F\left(z_{i}\right)-S\left(z_{i}\right)\right|$. The critical area is $D K=\left\{L \mid L>L_{\alpha} n\right\}$, based on the table of critical values Lilliefors, it is obtained $L_{0,05 ; 36}=0,148$. Samples come from the populations that are normally distributed when $L_{\text {hitung }}$ is not in a critical area (DK) $\left(L_{\text {observation }} \notin D K\right)$. Based on the test decisions, it is obtained that $L_{\text {observation }}<L_{\text {table }}$. It shows that each sample is normally distributed.

Normality test of creative thinking test. This test is to find out whether the sample is normally distributed or not. By using 
the Lilliefors method with a significance level of 0,05 , the test results can be seen in Table 3 .

Table 3. The analysis results of data normality test

\begin{tabular}{ccccc}
\hline Classes & $\begin{array}{c}\boldsymbol{L}_{\text {obser }} \\
\text { vation }\end{array}$ & $\boldsymbol{L}_{\text {table }}$ & $\begin{array}{c}\text { Test } \\
\text { Decisions }\end{array}$ & $\begin{array}{c}\text { Data } \\
\text { Distributions }\end{array}$ \\
\hline $\begin{array}{c}\text { Direct } \\
\text { Instruction } \\
\text { Learning } \\
\text { Flipped }\end{array}$ & 0,1161 & 0,148 & Accepted & $\begin{array}{c}\text { Normal } \\
\text { Distribution }\end{array}$ \\
$\begin{array}{c}\text { Classroom } \\
\text { Learning by } \\
\text { using Edmodo } \\
\text { apps }\end{array}$ & 0,1223 & 0,148 & Accepted & $\begin{array}{c}\text { Normal } \\
\text { Distribution }\end{array}$ \\
\hline
\end{tabular}

The amount of sample in both groups is $n=36$ with a significance level of $\alpha=5 \%$. The value of $L_{\text {hitung }}$ is obtained from the formula $L=\operatorname{Maks}\left|F\left(z_{i}\right)-S\left(z_{i}\right)\right|$. The critical area is $D K=\left\{L \mid L>L_{\alpha ; n}\right\}$, based on the table of critical values Lilliefors, it is obtained $L_{0,05 ; 36}=0,148$. Samples come from the populations that are normally distributed when $L_{\text {hitung }}$ is not in a critical area (DK) $\left(L_{\text {observation }} \notin D K\right)$. Based on the test decisions, it is obtained that $L_{\text {observation }}<L_{\text {table }}$. It shows that each sample is normally distributed.

\subsubsection{Homogeneity test}

Homogeneity test of final examination. Homogeneity test is used to determine whether the varians of both populations are homogeneous or not. Testing between the two groups uses the Bartlet test with a significance level of 0,05 . The results of homogeneity test can be seen in Table 4 .

Table 4. The analysis results of data homogeneity test in final examination

\begin{tabular}{ccccc}
\hline Classes & $\begin{array}{c}\chi_{\text {obser }}^{2} \\
\text { vation }\end{array}$ & $\chi^{2}$ table & $\begin{array}{c}\text { Test } \\
\text { Decisions }\end{array}$ & Conclusions \\
\hline $\begin{array}{c}\text { Control and } \\
\text { Experimental }\end{array}$ & 0,0196 & 3,841 & $\begin{array}{c}\mathrm{H}_{0} \text { is } \\
\text { accepted }\end{array}$ & $\begin{array}{c}\text { Homogeneous } \\
\text { Samples }\end{array}$ \\
\hline
\end{tabular}

The significance level is $\alpha=5 \%$ and the amount of sample is $\mathrm{k}=2$. The critical area used is $D K=\left\{\chi^{2} \mid \chi^{2}>\chi_{\alpha, \mathrm{k}-1}\right\}$, based on the value of $\chi^{2}$ it is obtained that $\chi_{0,05 ; 1}^{2}=3,841$. The value of $\chi_{\text {observation }}^{2}$ is 0,0196 so $\chi_{\text {observation }}^{2}$ is not in the critical area $\left(\chi_{\text {observation }}^{2} \notin \mathrm{DK}\right)$. Based on the test decisions, the value of $\chi_{\text {observation }}^{2}<\chi_{\text {table }}^{2}$ it can be concluded that the samples come from the homogeneous population.

Table 5. The analysis results of data homogeneity test

\begin{tabular}{ccccc}
\hline Classes & $\begin{array}{c}\chi_{\text {obser }}^{2} \\
\text { vation }\end{array}$ & $\chi_{\text {table }}^{2}$ & $\begin{array}{c}\text { Test } \\
\text { Decisions }\end{array}$ & Conclusions \\
\hline Direct & & & & \\
Instruction & & & & \\
Learning & & & & \\
and Flipped & & 3,841 & Accepted & $\begin{array}{c}\text { Homogeneous } \\
\text { Samples }\end{array}$ \\
Classroom & 0,12 & 3,84 & \\
Learning by & & & & \\
using & & & & \\
Edmodo & & & & \\
apps & & & & \\
\hline
\end{tabular}

Homogeneity test of creative thinking test. Homogeneity test is used to determine whether the population is homogeneous or not. Testing between the two groups uses the
Chi Square test with a significance level of 0,05 . The results of homogeneity test can be seen in Table 5 .

The significance level is $\alpha=5 \%$ and the amount of sample is $\mathrm{k}=2$. The critical area used is $D K=\left\{\chi^{2} \mid \chi^{2}>\chi_{\alpha, \mathrm{k}-1}^{2}\right\}$, based on the value of $\chi^{2}$ it is obtained that $\chi_{0,05 ; 1}^{2}=3,841$. The value of $\chi_{\text {observation }}^{2}$ is 0,12 so $\chi_{\text {observation }}^{2}$ is not in the critical area ( $\left.\chi_{\text {observation }}^{2} \notin \mathrm{DK}\right)$. Based on the test decisions, the value of $\chi_{\text {observation }}^{2}<\chi_{\text {table }}^{2}$ it can be concluded that the samples come from the homogeneous population.

\subsection{Hypothesis testing}

The hypotheses of this study are:

$\mathrm{H}_{0}$ : There is no influence of Edmodo apps on flipped classroom learning to the students' creative thinking ability in the course of Indonesian Language and Literature Study.

$\mathrm{H}_{1}$ : There is an influence of Edmodo apps on flipped classroom learning to the students' creative thinking ability in the course of Indonesian Language and Literature Study.

The hypothesis testing is done using t-test formula. The results can be seen in Table 6 .

Table 6. The analysis results of hypothesis testing

\begin{tabular}{ccccc}
\hline Classes & $\begin{array}{c}\boldsymbol{t}_{\text {obser }} \\
\text { vation }\end{array}$ & $\boldsymbol{t}_{\text {table }}$ & $\begin{array}{c}\text { Test } \\
\text { Decisions }\end{array}$ & Conclusion \\
\hline $\begin{array}{c}\text { Direct } \\
\text { Instruction }\end{array}$ & & & & \\
Learning and & & & & \\
Flipped & $-6,134$ & 2,2906 & $\begin{array}{c}\mathrm{H}_{0} \text { is } \\
\text { rejected }\end{array}$ & $\begin{array}{c}\text { There is an } \\
\text { influence }\end{array}$ \\
$\begin{array}{c}\text { Classroom } \\
\text { Learning by }\end{array}$ & & & & \\
using Edmodo & & & & \\
apps & & & & \\
\hline
\end{tabular}

Based on the test decisions with a significance level of 0,05 it is obtained that $t_{\text {observation }}=-6,134$ while $t 0,025 ; 70=2,2906$ and $D K=\{t \mid t<-2,2906$ or $\mathrm{t}>2,2906\}$. It can be concluded that there is an influence of Edmodo apps on flipped classroom learning to the students' creative thinking ability in the course of Indonesian Language and Literature Study.

It can be concluded that there is a suitability between the test decision and research hypothesis which shows that the use of Edmodo apps in flipped classroom learning gives better influence on students' creative thinking ability rather than direct instruction learning.

\subsection{Observation results}

Based on the result of observations, the implementation of Edmodo apps in flipped classroom learning in the course of Indonesian Language and Literature Study creates an average score of 70 for the control class's creative thinking ability, while the average score of experimental class is 81 . The students' learning activities are included into good category for each indicator that is $75,69 \% ; 72,74 \% ; 70,65 \% ; 74,65 \%$; $73,09 \%$; and 74,39\%. So, there is an influence of Edmodo apps on flipped classroom learning to the students' creative thinking ability in the course of Indonesian Language and Literature Study. 
The suitability of the test decisions and research hypothesis is due to the learning activities using Edmodo apps in flipped classroom leads the students to be able to develop their creative thinking ability. They can understand, identify, solve, and conclude the problems. Furthermore, they can work together, be responsible, and help each other in analysing and solving the problems faced in the course of Indonesian Language and Literature Study. Zainuddin says that the authors believe that the study on students' intrinsic motivation has been widely conducted in online community learning or emerging technology [33]. This is a cause of globalization era and free market causes many problems in every context of living [34].

A study by Serin and Khabibullin reveals that Edmodo apps can be used in flipped classroom learning to make students have online participations such as filling the diaries, surveys, and online tests [35]. Edmodo apps in flipped classroom learning is considered to be useful and effective because it can be used interactively to improve students' digital literacy skill [36].

\section{CONCLUSION}

Based on the results of research that has been done about the influence of Edmodo apps in flipped classroom learning on the students' creative thinking ability in the course of Indonesian Language and Literature Study, it is obtained that $t_{\text {observation }} \in D K$ yaitu $t_{\text {observation }}=-6,134$ and $D K=\{t \mid t<-$ $2,2906$ atau $\mathrm{t}>2,2906\}$, it can be concluded that the use of Edmodo apps in flipped classroom learning gives a better influence on the students' creative thinking ability in the course of Indonesian Language and Literature Study.

\section{ACKNOWLEDGMENT}

This work is supported by LPPM Universitas PGRI Madiun, LPPM IKIP PGRI Bojonegoro, LPPM Universitas Sebelas Maret, and LPPM Universitas Terbuka.

\section{REFERENCES}

[1] Keraf, G. (2015). Diksi dan Gaya Bahasa. Jakarta, Indonesia: Gramedia Pustaka Utama.

[2] Canette L.H., Lalitte P., Bedoin, N., Pineau, M., Bigand, E., Tillmann, B. (2020). Rhythmic and textural musical sequences differently influence syntax and semantic processing in children. Journal of Experimental Child Psychology, 191(104711): 1-19. https://doi.org/10.1016/j.jecp.2019.104711

[3] Levine, D., Pace, A., Luo, R., Hirsh-pasek, K., Golinkoff, R.M., Villiers, J.D., Iglesias, A., Wilson, M.S. (2018). Evaluating socioeconomic gaps in preschoolers' vocabulary, syntax and language process skills with the Quick Interactive Language Screener (QUILS). Early Childhood Research Quarterly, 50(2020): 114-128. https://doi.org/10.1016/j.ecresq.2018.11.006

[4] Liu, W., Branigan, H.P., Zheng, L., Long, Y., Bai, X., Kanyu, L., Zhao, H., Zhou, S., Pickering, M.J., Lu, C. (2019). Shared neural representations of syntax during online dyadic communication. Neurolmage, 198: 63-72. https://doi.org/10.1016/j.neuroimage.2019.05.035
[5] White, L.J., Alexander, A., Greenfield, D.B. (2017). The relationship between executive functioning and language: Examining vocabulary, syntax, and language learning in preschoolers attending Head Start. Journal of Experimental Child Psychology, 164: 16-31. http://dx.doi.org/10.1016/j.jecp.2017.06.010

[6] Ramlan. (2005). Ilmu bahasa Indonesia: Sintaksis. Yogyakarta, Indonesia: Karyono.

[7] Hasanudin, C. (2018). Kajian sintaksis pada novel Sang Pencuri Warna karya Yersita [Syntactic Study on the novel entitled "The Colours Thief" by Yersita]. Jurnal Pendidikan Edutama, 5(2): 19-30. http://dx.doi.org/10.30734/jpe.v5i2.191

[8] Munandar, U. (2000). Pengembangan kreativitas anak berbakat. Jakarta, Indonesia: Rineka Cipta.

[9] Pehkonen, E. (1997). The state-of-art in mathematical creativity. ZDM, 29(3): https://doi.org/10.1007/s11858-997-0001-z

[10] Hasanudin, C., Fitrianingsih, A. (2020). Verbal linguistic intelligence of the first-year students of Indonesian education program: A case in reading subject. European Journal of Educational Research, 9(1): 117-128. https://doi.org/10.12973/eu-jer.9.1.117

[11] Hassoubah, I.Z. (2004). Developing creatif and critical thinking skill. Bandung, Indonesia: Nuansa.

[12] Saddhono, K., Hasanudin, C., Fitrianingsih, A. (2019). The ability to think creatively on SSCS using schoology Apps, how is the student's language metacognitive awareness? Ingénierie des Systèmes d'Information, 24(4): 367-375. https://doi.org/10.18280/isi.240402

[13] Hidayat, R. (2010). Pembelajaran kontekstual dengan strategi react dalam upaya pengembangan kemampuan pemecahan masalah, berpikir kritis, dan berpikir kreatif matematis mahasiswa bidang sains. Thesis, Universitas Pendidikan Indonesia, Bandung, Indonesia. http://repository.upi.edu/8017/

[14] Retnowati, R., Suharyati, H., Manurung, R.T., Maknun, D., Armariena, D.N., Hetilaniar, H., Hasanudin, C., Murniviyanti, L., Anwar, S., Setyorini, R. (2018). The effect of environmental teaching method and the level of natural intelligence on the environmental view of the students behavior. Journal of Physics: Conference Series, 1114(1): https://doi.org/10.1088/17426596/1114/1/012104

[15] Akçayır, G., Akçayır, M. (2018). The flipped classroom: A review of its advantages and challenges. Computers \& Education, 126 334-345. https://doi.org/10.1016/j.compedu.2018.07.021

[16] Lai, C.L., Hwang, G.J. (2016). A self-regulated flipped classroom approach to improving students' learning performance in a mathematics course. Computer \& Education, 100: 126-140. https://doi.org/10.1016/j.compedu.2016.05.006

[17] Lo, C.K., Hew, K.F., Chen, G. (2017). Toward a set of design principles for mathematics flipped classrooms: A synthesis of research in mathematics education. Educational Research Review. 22: 50-73. https://doi.org/10.1016/j.edurev.2017.08.002

[18] Bergmann, J., Sams, A. (2012). Flip Your Classroom: Reach Every Student in Every Class Every Day. Washington, DC: Internal Society for Technology in Education.

[19] Hasanudin, C., Fitrianingsih, A. (2018). The implementation of flipped classroom using screencast- 
o-matic to improve students' verbal linguistic intelligence. International Journal of Engineering \& Technology, 7(4.15): 435-439. https://doi.org/10.14419/ijet.v7i4.15.23602

[20] Murillo-Zamorano, L.R., Sánchez, J.Á.L., GodoyCaballero, A.L. (2019). How the flipped classroom affects knowledge, skills, and engagement in higher education: Effects on students' satisfaction. Computer Education, 141(103608): 1-18. https://doi.org/10.1016/j.compedu.2019.103608

[21] Hasanudin, C., Fitrianingsih, A., Saddhono, K. (2019). How is the student's negotiation text in collaborative learning of flipped classroom and a CyberLink power director media Apps. Ingénierie des Systèmes d'Information, 24(6): 559-567. https://doi.org/10.18280/isi.240601

[22] Hasanudin, C., Fitrianingsih, A., Saddhono, K. (2019). The use of wondershare filmora version 7.8.9 media apps in flipped classroom teaching. Review of Computer Engineering Studies, 6(3): 51-55. https://doi.org/10.18280/rces.060301

[23] Mahfudin, A. (2013). Efektifitas penggunaaan edmodo sebagai media penunjang dasar pembelajaran di SMKN 1 Majalengka. Thesis, Universitas Pendidikan Indonesia, Bandung, Indonesia. http://repository.upi.edu/334/1/S_TB_0908717_TITLE. pdf.

[24] Balasubramanian, K., Jaykumar, V., Fukey L.N. (2014). A study on "Student preference towards the use of Edmodo as a learning platform to create responsible learning environment". Procedia - Social and Behavioral Sciences, 144: 416-422. https://doi.org/10.1016/j.sbspro.2014.07.311

[25] Tania1, R., Jumadi, Astuti, D.P. (2020). The application of physics e-handout assisted by PBL model use Edmodo to improve critical thinking skills and ICT literacy of high school students. Journal of Physics: Conference Series, 1440(1): 1-7. https://doi.org/10.1088/1742$6596 / 1440 / 1 / 012037$
[26] Pertiwi, A., Kariadinata, R., Juariah, J., Sugilar, H., Ramdhani, M.A. (2019). Edmodo-based blended learning on mathematical proving capability. Journal of Physics: Conference Series, 1157(4): 1-6. https://doi.org/10.1088/1742-6596/1157/4/042001

[27] Çankaya, S., Durak, G., Yünkül, E. (2013). Using educational social networking sites in higher education: Edmodo through the lenses of undergraduate students. European Journal of Educational Technology, 1(1): 3-23.

[28] Sugiyono. (2015). Metode Penelitian Pendidikan: Pendekatan Kuantitatif, Kualitatif, dan R\&D. Bandung, Indonesia: Alfabeta.

[29] Sugiyono. (2013). Statistika Untuk Penelitian. Bandung, Indonesia: CV Alfabeta.

[30] Arikunto, S. (2013). Prosedur Penelitian: Edisi Revisi. Jakarta, Indonesia: Rineka Cipta

[31] Arikunto, S. (2006). Prosedur Penelitian. Jakarta, Indonesia, Rineka Cipta.

[32] Arikunto, S. (2012). Dasar-dasar Evaluasi Pendidikan. Jakarta, Indonesia: PT Bumi Aksara.

[33] Zainuddin, Z. (2018). Students' learning performance and perceived motivation in gamified flipped-class instruction. Computers \& Education, 126: 75-88. https://doi.org/10.1016/j.compedu.2018.07.003

[34] Brata, D.N.P., Mahatmaharti, RR.A.K., Istianingrum, R., Hasanudin, C., Hadi, S. (2020). Developing Pancasila and Civic Education (PPKN) based on local wisdom. Humanities \& Social Sciences Reviews, 8(1): 768-773. https://doi.org/10.18510/hssr.2020.8192

[35] Serin, H., Khabibullin, A. (2019). Flipped classrooms in teaching method courses at universities. International Journal of Academic Research in Business and Social Sciences, $9(1)$ : 573-585. http://dx.doi.org/10.6007/IJARBSS/v9-i1/5459

[36] Erdemir, N., Ekşi-Yangın, G. (2019). The perceptions of student teachers about using an online learning environment 'Edmodo' in a 'flipped classroom'. SDU International Journal of Educational Studies, 6(2): 174186. https://doi.org/10.33710/sduijes.638795 